\title{
Finance-Growth Nexus in Bangladesh: Is it Important to Quantify Financial Development?
}

\author{
Uttam Golder ${ }^{1, *}$, Fatema Sultana ${ }^{2}$, Mohammad Kamal Hossain ${ }^{3}$, Mohammad Awal Hossen², \\ Md. Monzur Hossain ${ }^{4}$ \\ ${ }^{1}$ Department of Finance and Banking, Jashore University of Science and Technology, Jashore-7408, Bangladesh \\ ${ }^{2}$ Department of Management, Jashore University of Science and Technology, Jashore-7408, Bangladesh \\ ${ }^{3}$ Department of Accounting and Information Systems, Jashore University of Science and Technology, Jashore-7408, Bangladesh \\ ${ }^{4}$ Department of Finance and Banking, Comilla University, Cumilla- 3506, Bangladesh
}

Received July 6, 2021; Revised August 12, 2021; Accepted September 21, 2021

\section{Cite This Paper in the following Citation Styles}

(a): [1] Uttam Golder, Fatema Sultana, Mohammad Kamal Hossain, Mohammad Awal Hossen, Md. Monzur Hossain, "Finance-Growth Nexus in Bangladesh: Is it Important to Quantify Financial Development?," Universal Journal of Accounting and Finance, Vol. 9, No. 5, pp. 961 - 971, 2021. DOI: 10.13189/ujaf.2021.090507.

(b): Uttam Golder, Fatema Sultana, Mohammad Kamal Hossain, Mohammad Awal Hossen, Md. Monzur Hossain (2021). Finance-Growth Nexus in Bangladesh: Is it Important to Quantify Financial Development?. Universal Journal of Accounting and Finance, 9(5), 961 - 971. DOI: 10.13189/ujaf.2021.090507.

Copyright $\bigcirc 2021$ by authors, all rights reserved. Authors agree that this article remains permanently open access under the terms of the Creative Commons Attribution License 4.0 International License

\begin{abstract}
This study aims to examine empirically whether financial development can promote economic growth in Bangladesh. It employs the Autoregressive Distributed Lag (ARDL) model and takes annual data from 1987 to 2019. This study confirms a cointegrating relationship between financial development and economic growth. The nature of this relationship is unidirectional, running from financial development to economic growth. The outcome of the study confirms that financial development, as proxied by private sector loans and broad money supply, augments economic growth in the long-run. As for the control variables, gross domestic savings show an insignificant impact on economic growth when private sector loans are proxied for financial development. However, it confirms a substantial impact on economic growth when broad money supply is proxied for financial development. More interestingly, trade openness, another control variable, suggests an adverse impact on economic growth in the long-run. However, it has a substantial positive influence on economic growth in the short-run. In the short-run, broad money supply at lag 2 and gross domestic savings significantly affect economic growth when broad money supply is proxied for financial development. The findings of this study advocate that a robust and dynamic financial structure in Bangladesh is a critical success factor for developing the country's economic growth.
\end{abstract}

Keywords Financial Development, Economic Growth, Gross Domestic Savings, Trade Openness, Bangladesh

\section{Introduction}

Bangladesh is one of the smallest countries in the world, located in the Indian subcontinent. The country achieved independence through a bloody struggle in 1971. Economic reformation and development for the fragile nation was a challenge for the former governments in the post-independence period. The development of the agricultural and industrial sectors was the only option to meet the basic needs of the post-war country's people while also restoring the country's weak economy. Surprisingly, Bangladesh has emerged as a role model in the world in a variety of social and economic development areas in a relatively short period of time. According to the World Bank, the GDP growth rate of the country was $8.15 \%$, and the per capita GDP was 1855.74 US dollars in 2019 [1]. Bangladesh, followed by Bhutan, was one of the two countries that achieved nonnegative GDP growth of $5.2 \%$ during the COVID-19 pandemic situation in 2020 among the South Asian countries, while the region's overall GDP shrank by $6 \%$, as reported by the Asian 
Development Bank [2]. It also predicted that Bangladesh would be the second-fastest-growing GDP country in South Asia in 2022, with a growth rate of 7.2\% [2]. Figure 1 shows the time series plots of gross domestic products, private sector credit, broad money supply, gross domestic savings, and trade openness, indicating an upward trend with the passing of time.

The stock market and the banking industry are regarded as two important pillars for any country's economic development. Bangladesh has two stock markets, but they are still immature [3], [4]. The banking sector, as a provider of small, medium, and large loans, plays the most substantial role in the ultimate economic growth of the country. This reality emphasises the role of financial progress in the growth of a country. However, observational research on the finance-growth relationship reveals a mixed outcome. Some researchers have found a bi-directional link [5], [6] between finance and growth, while some others have revealed a unidirectional relationship [7]-[9].
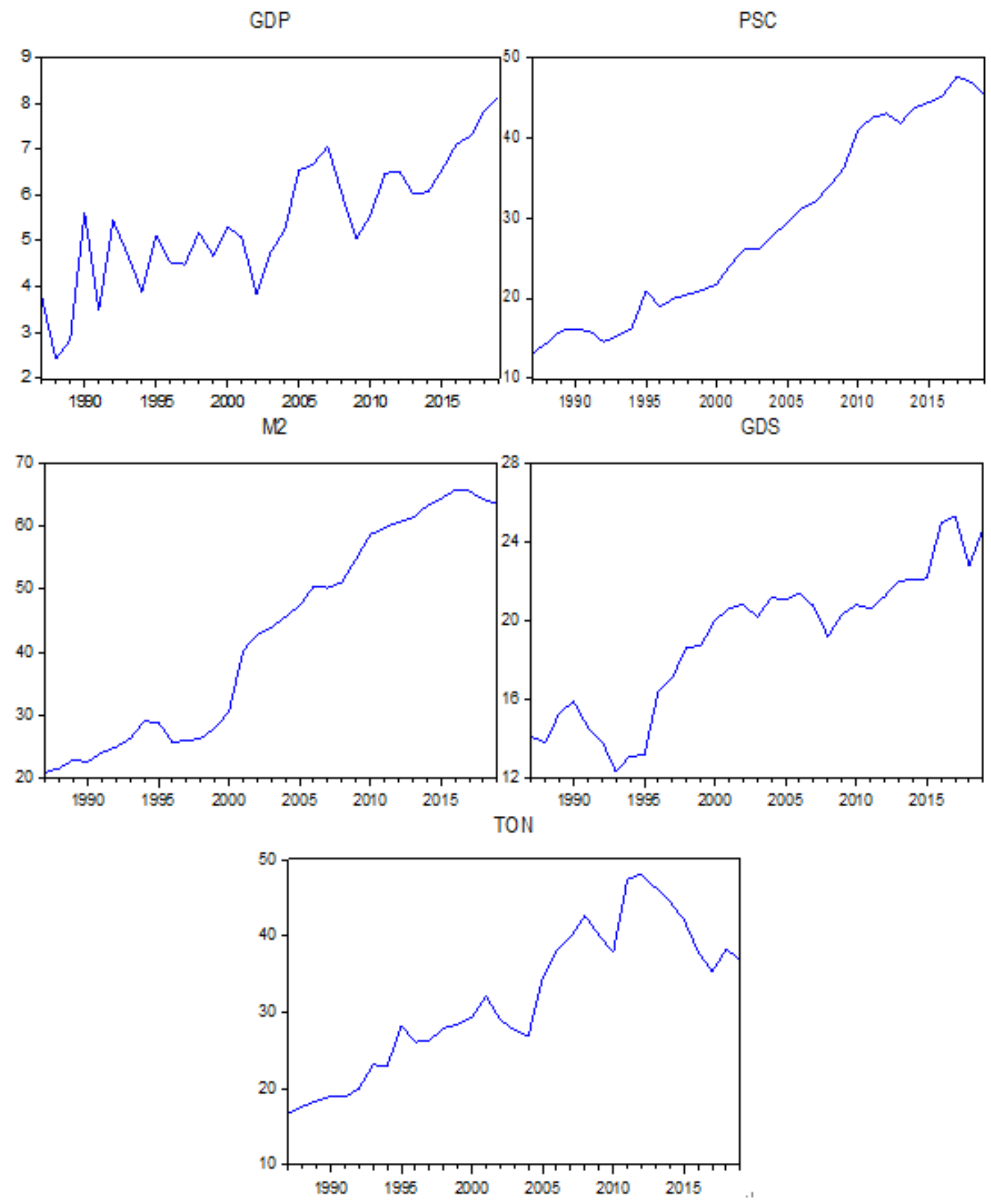

Figure 1. Time series plots of the variables 
Several studies undertaken on various countries also found diverse outcomes. Many have shown that finance and growth have a plausible positive relationship, while others have shown a considerable negative link. Previous studies on Bangladesh have not been without criticism. For example, a recent study conducted by Amin and Hossain [10] looks into the finance-growth nexus. This study, however, only finds a causal association between the two variables, with no evidence of any other cointegration. Moreover, it is difficult to conclude whether the model is stable. The study undertaken by Shahbaz et al. [11], which investigates the role of financial progress in the economic success of Bangladesh by analyzing annual data from 1976 to 2012, suffers from the problem of serial correlation. Later, Biplob and Halder [12] reveal the connection between finance and growth. Functional misspecification may, however, exist in the study because no test was performed to check it.

Therefore, and in contrast to earlier studies on Bangladesh, this study aims to examine the relationship between finance and growth using the ARDL model. This study applies unit root assessment to avoid spurious relationships and present accurate coefficients of regression. The ARDL approach determines the nature of the relationship between the variables. The current study also ensures the absence of serial correlation, heteroskedasticity, and functional misspecification. Also, the existence of normality and stability of the models are ensured. A noteworthy feature of the study is that it uses two different proxies for financial development in two different models and seeks to view their contribution to economic growth from different perspectives. At the same time, attempts have been made to find a solution to whether economic growth is affecting financial development or whether financial development influences economic growth.

This study endeavors to extend the existing body of knowledge in the relevant field. It provides new insights for both government and non-government organizations contributing to Bangladesh's economic growth. The findings may be helpful for the banking sector and the central bank of Bangladesh, as the study is expected to provide evidence of the role of a growing volume of money supply in the open market. At the same time, conventional banks are expected to understand the role of private sector lending in the country's economic growth.

\section{Literature Review}

There is a theoretical and empirical paradox about the relationship between financial development and economic growth. There are at least two theoretical causes that express why finance can influence economic growth. First, several major scholars in macroeconomics believe that finance might devour an excessive amount of human capital (e.g., skilled and brilliant employees) [13]. Cecchetti and Kharroubi [14] argue, for example, that finance, especially human resources, is competing with the rest of the economy. From this point of view, finance represents a barrier to economic progress by consuming a huge number of highly trained and brilliant individuals. Beck et al. [15] also support this perspective. This overabundance of human capital is associated with the highly specialized labor supplies needed for the trade in complicated financial products. Second, Hyman Minsky's original theory of financial instability provides another perspective [16]. According to this premise, the economic system has an inherent propensity to shift from a stable to a poor economic situation. A good economic situation during a period of growth enables agents to increase their trust and hopes. This increasingly pushes borrowers into larger financial contacts in comparison to their real financial capability; similarly, creditors steadily lower their creditworthiness criteria and offer credit supply to borrowers.

Besides, financial development indirectly affects economic development through its direct impact on savings and investments. Financial institutions, especially banks, diversify their portfolios by collecting deposits from the public and by investing in various industries. Thus, it boosts consumers' financial stability while also providing a stable source of income. Moreover, small-and medium-sized businesses promote economic development through the financial sector by taking credit and boosting their earnings [17].

Levine [18] suggests that by allocating resources, tracking corporate governance, dropping losses, animating savings, and smoothing transactions, the financial system revises the difficulties resulting from market frictions. Early works performed by Schumpeter and Opie [19] and Goldsmith [20] identify specific vital tasks of the banking system, such as savings distribution, promoting innovation, and financing profitable uses, all of which lead to economic progress. Another prior work conducted by Hasan and Barua [21] reveals that a well-developed financial system reduces the cost of business transactions, information, and monitoring. According to Anwar and Nguyen [7], financial growth alters a range of policies as the host country's capital rises. It promotes technological innovation, and simultaneously, innovation promotes human capital growth. Increasing human capital leads to augmented economic success in the country. Wolde-Rufael [22] identifies that the expansion of countries with advanced financial systems is faster than others. Besides, the deficient portions of the population can keep up with the country's overall economic progress.

In contrast, another school of thought believes that too much or excessive finance weakens economic growth. The point emphasized in this notion is that unnecessary expansion in the financial division will remove human capital, increase financial instability, and make the overall 
economy more prone to economic decline [23].

Recently, an empirical study undertaken by R. Pradhan [24] finds a signal of a constructive outcome of financial progress on growth employing the VAR model. This study identifies a long-standing relationship of collaboration between the two in India. Lastly, it concludes that the vitality of the country's economic growth will stimulate financial advancement. Simultaneously, the dynamism of financial development will accelerate growth in the economy. Durusu-Ciftci et al. [25] investigate the long-term association between financial development and growth, taking data from 40 nations from 1989 to 2011. This study confirms increased growth through the development of the financial industry. It recommends policymakers for the well-founding of the financial industry. Similarly, Arestis et al. [8] also find a strong favorable connection between financial expansion and growth. Biplob and Halder [12] re-examine the finance-growth nexus using the VECM approach and find a unidirectional connection between the two forms of financial advancement to growth. The importance of the financial industry's growth for the overall progress of the economy, particularly credit circulation in the private sector and the beneficial influence of gross domestic savings and investment, has been highlighted in the study. Edet [26] and Udoh et al. [27] conduct two distinct studies, revealing a significant relationship between financial development and economic growth and a bi-directional causal relationship between the two. Along the lines of previous studies, a parallel analysis by Ang [28] also identifies finance as the foremost determinant for driving growth in Malaysia, and acknowledges private savings and investment as two essential elements influencing growth. Another recent study, which uses panel data of 61 provinces for the period 1997 to 2006 and employs a panel GMM model, conducted by Anwar and Nguyen [7], suggests a favorable association between finance and growth in Vietnam. When gross domestic savings and broad money supply are employed as alternative measurements for financial development, they also find similar results.

The consequence of finance on growth has also been studied by Shahbaz et al. [11], who demonstrate a promising positive impact on growth. Furthermore, this study advocates that trade openness has a favorable effect on growth. Bist and Bista [9] conduct a study with a structural break using the ARDL model and taking annual data ranging from 1984 to 2014. This study also finds a significant positive and one-way relationship running from finance to growth in Nepal. Gross domestic credit and trade openness are found to have a negative link with growth. A recent study on Pakistan undertaken by Rahman et al. [29], which employs the Markov switching model and takes data from 1980 to 2018, confirms the promotion of growth by finance in both high and low economic growth states, with higher growth in the high-income areas. Besides, government expenditures and trade openness have been discovered to have a productive association with growth. Jahfer and Inoue [30] explore the association between financial sector expansion and growth, which finds a bi-directional casualty and long-run linkage between the two. R. P. Pradhan et al. [31] agree with earlier academics and suggest that people outside the banking facilities should be integrated to achieve genuine economic success. Besides, credit circulation to the private sector, broad money supply, gross capital creation, and trade openness positively influence growth, as suggested by Qamruzzaman and Jianguo [32].

However, the nexus between finance and growth may not be as typical as the classic works suggest, according to Adu et al. [17]. This analysis demonstrates that the influence of finance on growth is conditional on the proxy for financial progress chosen and that private sector lending has a positive influence on growth. However, the money supply has no growth-stimulating effects. Hasan and Barua [21] revisit the nexus of the finance-growth relationship and unexpectedly explored no notable influence of broad money supply and domestic credit on growth. The study argues that cash injected into the system lacks a relationship to economic activity. Iheanacho [33] confirms the insignificant negative connection between finance and growth in the long-term, whereas demonstrating a significant negative association in the short-term. Further, Siddikee and Rahman [34] find an insignificant effect of finance on growth in the short term. In the long term, they find a negative association between the two, indicating the weakness of the banking sector.

In sum, the finance-growth nexus and their causal relationship are not consistent. It provides evidence of positive, negative, and sometimes insignificant or no effects of finance on growth. The outcomes vary based on the socioeconomic structure and location of the country. Therefore, this study attempts to reassess the relationship between finance and the growth of Bangladesh.

\section{Methodology}

The foremost motivation for this study is to explore the long-term impact of financial development on the economic growth of Bangladesh. This study incorporates gross domestic savings (GDS) and trade openness (TON) into the model as control variables to understand the real long-term association between the variables. Yearly data series for the period 1987 to 2019 have been used to analyse this relationship. Data series are collected from the World Bank, the highly relevant and credible global repository for economic data. For analysis purposes, this study employs the following equations based on the previous literature.

$$
G D P_{t}=\phi_{0}+\phi_{1} P S C_{t}+\phi_{2} G D S_{t}+\phi_{3} T O N_{t}+\varepsilon_{t}
$$




$$
G D P_{t}=\phi_{0}+\phi_{1} M 2_{t}+\phi_{2} G D S_{t}+\phi_{3} T O N_{t}+\varepsilon_{t}
$$

Since the causal relationship between financial development and economic growth is unclear, this study pursues the method of Bist and Bista [9] and Christopoulos and Tsionas [35] to address the causal relationship. Therefore, the following equations are formulated as:

$$
\begin{aligned}
& P S C_{t}=\phi_{0}+\phi_{1} G D P_{t}+\phi_{2} G D S_{t}+\phi_{3} T^{T O N_{t}}+\varepsilon_{t} \\
& M 2_{t}=\phi_{0}+\phi_{1} G D P_{t}+\phi_{2} G D S_{t}+\phi_{3} T O N_{t}+\varepsilon_{t}
\end{aligned}
$$

Here, all the equations are considered to be long-run associated. GDP, PSC, M2, GDS, and TON denote gross domestic product, private sector loans, broad money supply, gross domestic savings, and trade openness, respectively. In this study, economic growth is measured by the yearly growth rate of real gross domestic product (GDP). PSC and M2 are used as the two proxies for financial development. PSC is measured by domestic loans provided to non-government sectors as a ratio to nominal GDP. M2 is measured by the sum of narrow money with savings deposits, small-denomination time deposits, and repo contracts as a proportion of nominal GDP. GDP minus final consumption expenses as a proportion of nominal GDP is used to measure GDS. Finally, the totality of exports and imports as a GDP ratio is employed as a proxy for TON. $\phi_{0}$ is constant, and $\varepsilon_{t}$ represents unobserved variables. $\phi_{1}, \phi_{2}$, and $\phi_{3}$ denote the coefficients of the predictor variables.

The Autoregressive Distributed Lag approach is used to ascertain the nexus between financial development and economic growth in Bangladesh. This approach is preferred over traditional methods such as the Johansen cointegration test and the Engle and Granger approach [36], [37]. Among the conditions in which ARDL gets relaxation, it is indispensable to note that not all existing variables need to be combined into the equivalent form. Still, those variables can be in the order of zero, one, or a combination of zero and one. Simultaneously, this analysis is also operative at a minimal sample size and estimates the short-term and long-term coefficients of the exogenous variables. However, this model cannot be expanded if any variable is incorporated into the second-order or above.

The ARDL model progresses in subsequent phases. All variables' stationarity is scrutinised in the first step via Augmented Dickey-Fuller (ADF) and Phillips Perron (PP) unit root tests. Both methods are used to cross-validate the results. Although stationarity checking is not compulsory for the ARDL model, it is done to know whether any of the model's variables are united in the second-order or above. In the second phase, the model's cointegration test is performed. Because of several advantages over other traditional cointegration techniques, this study uses the ARDL bounds testing approach. This analysis intends to examine the nexus between financial development and economic growth, employing ARDL models in equations
(5), (6), (7), and (8), in which the central issue is the measure and direction of the financial development coefficient. At the same time, the findings of the other control variables still provide some valuable perspectives.

$$
\begin{aligned}
& \Delta G D P_{t}=\alpha_{0}+\sum_{j=1}^{p} \gamma_{j} \Delta G D P_{t-j}+\sum_{j=0}^{q} \eta_{j} \Delta P S C_{t-j}+ \\
& \sum_{j=0}^{r} \lambda_{j} \Delta G D S_{t-j}+\sum_{j=0}^{S} \rho_{j} \Delta T O N_{t-j}+\omega_{1} G D P_{t-1}+ \\
& \omega_{2} P S C_{t-1}+\omega_{3} G D S_{t-1}+\omega_{4} T O N_{t-1}+\varepsilon_{t} \\
& \Delta G D P_{t}=\alpha_{0}+\sum_{j=1}^{p} \gamma_{j} \Delta G D P_{t-j}+\sum_{j=0}^{q} \eta_{j} \Delta M 2_{t-j}+ \\
& \sum_{j=0}^{r} \lambda_{j} \Delta G D S_{t-j}+\sum_{j=0}^{s} \rho_{j} \Delta T O N_{t-j}+\Psi_{1} G D P_{t-1}+ \\
& \Psi_{2} M 2_{t-1}+\Psi_{3} G D S_{t-1}+\Psi_{4} T O N_{t-1}+\varepsilon_{t} \\
& \Delta P S C_{t}=\alpha_{0}+\sum_{j=1}^{p} \gamma_{j} \Delta P S C_{t-j}+\sum_{j=0}^{q} \eta_{j} \Delta G D P_{t-j}+ \\
& \sum_{j=0}^{r} \lambda_{j} \Delta G D S_{t-j}+\sum_{j=0}^{s} \rho_{j} \Delta T O N_{t-j}+\theta_{1} P S C_{t-1}+ \\
& \theta_{2} G D P_{t-1}+\theta_{3} G D S_{t-1}+\theta_{4} T_{O N} N_{t-1}+\varepsilon_{t} \\
& \Delta M 2_{t}=\alpha_{0}+\sum_{j=1}^{p} \gamma_{j} \Delta M 2_{t-j}+\sum_{j=0}^{q} \eta_{j} \Delta G D P_{t-j}+ \\
& \sum_{j=0}^{r} \lambda_{j} \Delta G D S_{t-j}+\sum_{j=0}^{s} \rho_{j} \Delta T O N_{t-j}+\xi_{1} M 2_{t-1}+ \\
& \xi_{2} G D P_{t-1}+\xi_{3} G D S_{t-1}+\xi_{4} T O N_{t-1}+\varepsilon_{t}
\end{aligned}
$$

Here, $\alpha_{0}$ denotes constant, $\Delta$ symbolises the $1^{\text {st }}$ difference operator, $p, q, r$, and $s$ are lag orders. $\omega_{1}-\omega_{4}$, $\Psi_{1}-\Psi_{4}, \theta_{1}-\theta_{4}$, and $\xi_{1}-\xi_{4}$ denote the long-term shock of predictor variables on the response variable. Besides, $\sum_{j=0}^{q} \eta_{j}, \sum_{j=0}^{r} \lambda_{j}$, and $\sum_{j=0}^{S} \rho_{j}$ estimate the short-run impacts of independent variables on the dependent variable. The $F$-test is performed to check the presence of a long-term relationship measured by equations (5), (6), (7), and (8). By placing a zero-joint limit on $\omega_{s}, \Psi_{s}, \theta_{s}$, and $\xi_{s}$ in the error correction models, the test entails verifying the $H_{0}$ of no cointegration as $H_{O}: \omega_{1}=\omega_{2}=\omega_{3}=\omega_{4}=0, \quad H_{O}: \Psi_{1}=\Psi_{2}=\Psi_{3}=\Psi_{4}=0$, $H_{0}: \theta_{1}=\theta_{2}=\theta_{3}=\theta_{4}=0$, and $H_{0}: \xi_{1}=\xi_{2}=\xi_{3}=\xi_{4}=0$ in the respective models. The ARDL bounds testing methodology is used for this assessment, and the estimated $F$-statistic under the null hypothesis is given by equations (5), (6), (7), and (8). In this regard, Pesaran et al. [38] calculated two types of critical standards, with the first type assuming variables to be $\mathrm{I}(0)$ and the second type assuming they to be $\mathrm{I}(1)$, resulting in lower bounds and upper limit critical values, respectively. If $F$-statistic surpasses the crucial value of the upper bounds, this study rejects the $H_{0}$ of no-cointegration, which results in the combination of variables for long-run relationships. Conversely, if the estimated $F$-statistic is smaller than the critical standard of the lower bounds, this study accepts the null hypothesis, meaning that the variables cannot cointegrate. Contrariwise, the choice of a long-run association is unclear when the calculated $F$-statistic exists in the upper and lower bounds. In stage three, if the long-run association between variables is determined, ECM applies to the assessment of short-term coefficient and error correction term $(E C T)$. The ECM can be set as follows:

$$
\begin{array}{r}
\Delta G D P_{t}=\alpha_{0}+\sum_{j=1}^{p} \gamma_{j} \Delta G D P_{t-j}+\sum_{j=0}^{q} \eta_{j} \Delta P S C_{t-j}+ \\
\sum_{j=0}^{r} \lambda_{j} \Delta G D S_{t-j}+\sum_{j=0}^{s} \rho_{j} \Delta T O N_{t-j}+\varphi_{1} E C T_{t-1}+\varepsilon_{t}
\end{array}
$$




$$
\begin{gathered}
\Delta G D P_{t}=\alpha_{0}+\sum_{j=1}^{p} \gamma_{j} \Delta G D P_{t-j}+\sum_{j=0}^{q} \eta_{j} \Delta M 2_{t-j}+ \\
\sum_{j=0}^{r} \lambda_{j} \Delta G D S_{t-j}+\sum_{j=0}^{s} \rho_{j} \Delta T O N_{t-j}+\varphi_{2} E C T_{t-1}+\varepsilon_{t} \\
\Delta P S C_{t}=\alpha_{0}+\sum_{j=1}^{p} \gamma_{j} \Delta P S C_{t-j}+\sum_{j=0}^{q} \eta_{j} \Delta G D P_{t-j}+ \\
\sum_{j=0}^{r} \lambda_{j} \Delta G D S_{t-j}+\sum_{j=0}^{s} \rho_{j} \Delta T O N_{t-j}+\varphi_{3} E C T_{t-1}+\varepsilon_{t} \\
\Delta M 2_{t}=\alpha_{0}+\sum_{j=1}^{p} \gamma_{j} \Delta M 2_{t-j}+\sum_{j=0}^{q} \eta_{j} \Delta G D P_{t-j}+ \\
\sum_{j=0}^{r} \lambda_{j} \Delta G D S_{t-j}+\sum_{j=0}^{s} \rho_{j} \Delta T O N_{t-j}+\varphi_{3} E C T_{t-1}+\varepsilon_{t}
\end{gathered}
$$

Here, $\varphi_{s}$ denotes the quickness of adjustment, and $E C T_{t-1}$ denote lagged error correction term. The ECT output must be non-positive and statistically significant, which shows the time to adjust to the long-term balance if there is a short-term disturbance. Fourthly, some diagnostic tests (e.g., skewness, kurtosis, Jarque-Bera test) are performed to check the goodness of fit of the models.

\section{Results and Discussion}

Descriptive statistics of the study variables are presented in Table 1. Skewness estimations confirm that all variables are normally distributed. The Kurtosis statistics of the variables reveal that all variables are platykurtic except for GDP, which is mesokurtic. The Jarque-Bera test also confirms the normality of all the selected variables in the study.

Table 1. Descriptive statistics

\begin{tabular}{cccccc}
\hline Statistics & GDP & PSC & M2 & GDS & TON \\
\hline Mean & 5.4323 & 28.8897 & 42.7779 & 19.0733 & 31.7548 \\
Std. Dev. & 1.3774 & 11.7727 & 16.5255 & 3.6931 & 9.4104 \\
Skewness & -0.1205 & 0.2614 & 0.0613 & -0.3229 & 0.0574 \\
Kurtosis & 2.5921 & 1.5563 & 1.3957 & 2.0635 & 1.8776 \\
Jarque-Bera & 0.3087 & 3.2418 & 3.5595 & 1.7793 & 1.7504 \\
Probability & 0.8570 & 0.1977 & 0.1687 & 0.4108 & 0.4168 \\
\hline
\end{tabular}

This study uses two types of unit root tests, e.g., ADF and PP, to determine whether any of the variables employed in the study are combined into the second order. Table 2 summarises the outcomes of the unit-root assessment. Estimations of the ADF unit root test indicate that neither of these variables are stationary at $\mathrm{I}(0)$, but they become stationary at $\mathrm{I}(1)$ and constant with the trend. This study also uses the PP unit root test to cross-validate the results, where the outcome is the same as ADF in constant. On the contrary, the four variables (e.g., PSC, M2, GDS, and TON) appear to be stationary at the first difference; however, GDP is stationary at the level in the

\begin{tabular}{|c|c|c|c|c|}
\hline & \multicolumn{2}{|c|}{$\mathrm{ADF}$} & \multicolumn{2}{|c|}{ PP } \\
\hline Variables & $\mathrm{C}$ & CT & C & $\mathrm{CT}$ \\
\hline \multicolumn{5}{|c|}{$\mathrm{I}(0)$} \\
\hline GDP & -0.3095 & -2.4073 & -1.5384 & $-4.6171 * * *$ \\
\hline PSC & -0.2326 & -1.9813 & -0.1973 & -1.9364 \\
\hline M2 & -0.7335 & -2.1322 & -0.4724 & -1.7536 \\
\hline GDS & -0.7689 & -2.3346 & -0.7689 & -2.3922 \\
\hline TON & -1.5735 & -2.8789 & -1.5726 & -1.4326 \\
\hline \multicolumn{5}{|c|}{$\mathrm{I}(1)$} \\
\hline GDP & $-5.1293 * * *$ & $-5.0333 * * *$ & $-11.2309 * * *$ & - \\
\hline PSC & $-5.0618 * * *$ & $-4.9563 * * *$ & $-5.0079 * * *$ & $-4.8932 * * *$ \\
\hline M2 & $-3.7978 * * *$ & $-3.7296 * *$ & $-3.7432 * * *$ & $-3.6694 * *$ \\
\hline GDS & $-5.7026 * * *$ & $-5.5984 * * *$ & $-5.7031 * * *$ & $-5.5977 * * *$ \\
\hline TON & $-5.1593 * * *$ & $-5.2527 * * *$ & $-5.1470 * * *$ & $-5.3407 * * *$ \\
\hline
\end{tabular}
context of constant and trend. The mixed combination character and the lack of integration in the second difference imply that the long-run ARDL model may be estimated.
Table 2. Unit-root test

a*** and ** indicate the $p$-value is statistically significant at the $1 \%$ and $5 \%$ levels, respectively. " "- " Symbolises "not applicable." " I(0) and I(1) refer to the level and first difference, respectively. ${ }^{\mathrm{d}} \mathrm{C}$ and $\mathrm{CT}$ indicate constant and constant with the trend, respectively.

It is crucial in research to select a suitable lag length of the series before starting with the ARDL technique, as long-run relationship of variables relies on optimum lag size [39]. Introducing excess lags or applying fewer lags almost certainly omits factual information from the model and may result in inaccurate model estimates [40]. Considering this fact, this study determines lag size using the Akaike Information Criterion (AIC). Furthermore, bounds testing has been executed to find out if there is a relationship between the variables that are persistent over time. The empirical results presented in Table 3 show that the calculated $F$-statistics of 12.3529 and 13.7558 in models 1 and 2, respectively, exceed the highest critical limits $(5.61)$ at the $1 \%$ significance level. This result confirms a long-run relationship between GDP and regressors (PSC, GDS, and TON), and (M2, GDS, TON) in models 1 and 2, respectively. However, when financial development (PSC and M2) is employed as the dependent variable, there is no indication of cointegration or long-run relationship. Therefore, it may be concluded that the long-term causality between financial development and economic growth in Bangladesh is unidirectional. Based on bounds testing results, models 1 and 2 tend to be the long-term driving factors in determining the economic growth of Bangladesh. The findings are consistent with those of Bist and Bista [9] of Nepal, R. Pradhan [24] of India, and Amin and Hossain [10] of Bangladesh, which are from the same subcontinent. The results are also in line with Christopoulos and Tsionas [35] of Nigeria, which has a comparable degree of economic development to Bangladesh. 
Table 4 divulges the outcomes of long-run and short-run results of models 1 and 2 . Model 1 reveals that a $1 \%$ increase in PSC results in a $0.1645 \%$ rise in real GDP at the $1 \%$ level of significance. This result indicates that private sector loans have a positive effect on economic growth. Several previous studies (for example, Anwar and Nguyen [7], Arestis et al. [8], R. Pradhan [24], and Durusu-Ciftci et al. [25]) agree with this result. Private sector loans transmit additional funds into the financial system, increasing private sector investment and stimulating economic activity within a country. Several Bangladeshi studies, including those by Amin and Hossain [10], Hasan and Barua [21], and M. H. Rahman [41], agree with this outcome.

Table 3. Bounds test of the ARDL model

\begin{tabular}{|c|c|c|c|c|}
\hline $\begin{array}{c}\text { Model } \\
\text { Specification } \\
\end{array}$ & \multicolumn{2}{|c|}{ ARDL } & $F$ - Stat. & Outcomes \\
\hline \multicolumn{5}{|l|}{ Growth proxies: } \\
\hline \multicolumn{5}{|l|}{$\begin{array}{c}\text { GDP as } \\
\text { dependent } \\
\text { variable }\end{array}$} \\
\hline $\begin{array}{c}F_{G D P}(\mathrm{GDP} \mid \mathrm{PSC}, \\
\text { GDS, TON })\end{array}$ & \multicolumn{2}{|c|}{$(1,3,0,3)$} & $12.3529 * * *$ & Co-integration \\
\hline Model 2: & \multirow{2}{*}{\multicolumn{2}{|c|}{$(1,3,0,3)$}} & & \\
\hline $\begin{array}{c}F_{G D P}(\mathrm{GDP} \mid \mathrm{M} 2, \\
\text { GDS, TON })\end{array}$ & & & $13.7558 * * *$ & Co-integration \\
\hline \multicolumn{5}{|l|}{ Finance proxies: } \\
\hline \multicolumn{5}{|l|}{$\begin{array}{c}\text { PSC and M2 are } \\
\text { dependent } \\
\text { variables }\end{array}$} \\
\hline $\begin{array}{c}F_{P S C}(\mathrm{PSC} \mid \mathrm{GDP}, \\
\text { GDS, TON })\end{array}$ & \multicolumn{2}{|c|}{$(1,3,3,3)$} & 1.7771 & $\begin{array}{c}\text { No } \\
\text { cointegration }\end{array}$ \\
\hline Model 4: & \multirow{2}{*}{\multicolumn{2}{|c|}{$(1,0,0,0)$}} & & No \\
\hline $\begin{array}{c}F_{M 2}(\mathrm{M} 2 \mid \mathrm{GDP} \\
\text { GDS, TON })\end{array}$ & & & 1.6539 & cointegration \\
\hline \multirow{3}{*}{ Critical values } & $1 \%$ & $1 \%$ & $5 \%$ & $5 \%$ \\
\hline & Lower & Upper & Lower & Upper \\
\hline & 4.29 & 5.61 & 3.23 & 4.35 \\
\hline
\end{tabular}

a*** indicates the $p$-value is statistically significant at the $1 \%$ level.

In model 2 of Table 4, the empirical findings show that a $1 \%$ increase in M2 results in a $0.0859 \%$ growth in real GDP, suggesting that broad money supply has a positive impact on economic growth. Many prior studies, for example, Biplob and Halder [12] and Qamruzzaman and Jianguo [32], have confirmed the findings. This outcome suggests that the economic growth of Bangladesh largely depends on private sector loans and the supply of broad money. However, the long-run coefficient of GDS is not statistically significant in model 1 . The explanation might be that gross domestic savings are transferable in several underdeveloped countries, including Bangladesh, and might be redirected to mass consumption. A further argument might be that it could be used to fund non-development expenditures. This might cancel out the beneficial effect of gross domestic savings on growth.
In contrast, model 2 of Table 4 reveals that a $1 \%$ increase in GDS increases GDP by $0.1217 \%$ at the $5 \%$ level of significance, suggesting that gross domestic savings has a significant positive effect on economic growth. This outcome is in line with previous studies undertaken by Biplob and Halder [12]. However, the findings of trade openness in both models show similar types of results. This study finds that a $1 \%$ increase in trade openness in models 1 and 2 decreases GDP by $0.1164 \%$ and $0.0810 \%$, respectively. Although trade openness provides developing nations with the ability to get access to investment and products that lie between their current and advanced economies and gear up economic growth, in this case, the story of Bangladesh is entirely different. Several possible factors might cause the trade defects, increased trade fees, underdeveloped overland connections, poor human capital index, outdated technology, and the end result is adverse trade openness and growth relationships [9], [42].

The short-run result of PSC in model 1 of Table 4 is not statistically significant. Also, in model 2, the short-term coefficients of M2 are insignificant, except for lag 2, which has a negative impact on GDP. The possible reasons might be the unproductive and inefficient use of loans to private sectors, massive money laundering, and the excess supply of money in the market in the short-run. The outcomes of model 1 also suggest that the short-term coefficient of GDS is not statistically significant, but model 2 shows that it is positively related to GDP at the $5 \%$ significance level. Additionally, the results show the short-term coefficients of TON in both models to be positive and statistically significant, indicating that trade openness surely strengthens economic growth in the short-term.

The study shows that the coefficients of ECT are non-positive and significant. The ECT in model 1 of Table 4 is -1.2432 and statistically significant at the $1 \%$ level. It advocates that the regressors (i.e., PSC, GDS, and TON) and GDP have a solid long-term relationship. Similarly, the coefficient of ECT -1.1936 is also non-positive and significant at the $1 \%$ level of significance (see model 2 of Table 4). It shows the co-movement of regressors (i.e., M2, GDS, and TON) and GDP. The ECT coefficients indicate that the correction procedure to return equilibrium following a disruption is reasonably quick. More specifically, if there is a movement in GDP from short-term to long-term every year, it is corrected by $124.32 \%$ and $119.36 \%$ in models 1 and 2 , respectively.

Estimations of several diagnostic tests presented in Table 4 suggest that the two models satisfy all post-estimation tests. The $p$-values of the JB, LM, heteroskedasticity, and Ramsey RESET tests exceed the value of 0.05 . These estimations confirm the normality of the residuals, the absence of serial correlation and heteroskedasticity in both models. They also promise the 
non-appearance of any misspecification in the models. ensure the goodness of fit of the models. Lastly, estimations of the CUSUM and CUSUM-SQ tests

Table 4. Long-run and short-run estimates

\begin{tabular}{|c|c|c|c|c|c|}
\hline \multicolumn{3}{|c|}{ Model 1} & \multicolumn{3}{|c|}{ Model 2} \\
\hline Regressors & Coeff. & t-stat. & Regressors & Coeff. & t-stat. \\
\hline \multicolumn{6}{|c|}{ Long-run estimates } \\
\hline PSC & 0.1645 & $5.5857 * * *$ & M2 & 0.0859 & $4.7495 * * *$ \\
\hline GDS & 0.0874 & 1.8948 & GDS & 0.1217 & $2.5616^{* *}$ \\
\hline TON & -0.1164 & $-3.3031 * * *$ & TON & -0.0810 & $-2.7715^{* *}$ \\
\hline $\mathrm{C}$ & 2.9550 & $4.5180 * * *$ & $\mathrm{C}$ & 2.3889 & $3.8067 * * *$ \\
\hline \multicolumn{6}{|c|}{ Short-run estimates } \\
\hline$\triangle P S C$ & 0.0447 & 0.5517 & $\Delta M 2$ & -0.0498 & -0.9247 \\
\hline$\triangle P S C_{t-1}$ & -0.0091 & -0.0904 & $\Delta M 2_{t-1}$ & 0.0320 & 0.3959 \\
\hline$\Delta P S C_{t-2}$ & -0.1548 & -1.8981 & $\Delta M 2_{t-2}$ & -0.1390 & $-2.6738 * *$ \\
\hline$\triangle G D S$ & 0.1086 & 1.9036 & $\triangle G D S$ & 0.1452 & $2.6097 * *$ \\
\hline$\triangle T O N$ & 0.1078 & $2.8351 * *$ & $\triangle T O N$ & 0.1015 & $2.9997 * * *$ \\
\hline$\Delta T O N_{t-1}$ & 0.0633 & 1.1937 & $\triangle T O N_{t-1}$ & 0.0479 & 0.9933 \\
\hline$\Delta T_{O N-2}$ & 0.0981 & 2.0447 & $\triangle T O N_{t-2}$ & 0.0509 & 1.2817 \\
\hline$\Delta E C T_{t-1}$ & -1.2432 & $-7.3482 * * *$ & $\Delta E C T_{t-1}$ & -1.1936 & $-7.4705 * * *$ \\
\hline \multicolumn{6}{|c|}{ Diagnostic tests } \\
\hline \multicolumn{3}{|c|}{$X^{2}(p$-value $) /$ Stability } & \multicolumn{3}{|c|}{$X^{2}(p$-value $) /$ Stability } \\
\hline \multicolumn{2}{|c|}{ Jarque-Bera Test (JB) } & 0.8078 & & & 0.4580 \\
\hline \multicolumn{2}{|c|}{ Lagrange Multiplier Test (LM) } & 0.6406 & & & 0.7354 \\
\hline \multicolumn{2}{|c|}{ Heteroskedasticity Test } & 0.2261 & & & 0.5085 \\
\hline \multicolumn{2}{|c|}{ Ramsey RESET Test } & 0.1706 & & & 0.7540 \\
\hline \multicolumn{2}{|c|}{ CUSUM } & Stable & & & Stable \\
\hline \multicolumn{2}{|c|}{ CUSUM-SQ } & Stable & & & Stable \\
\hline
\end{tabular}

a*** and ** indicate the $p$-value is statistically significant at the $1 \%$ and $5 \%$ levels, respectively.
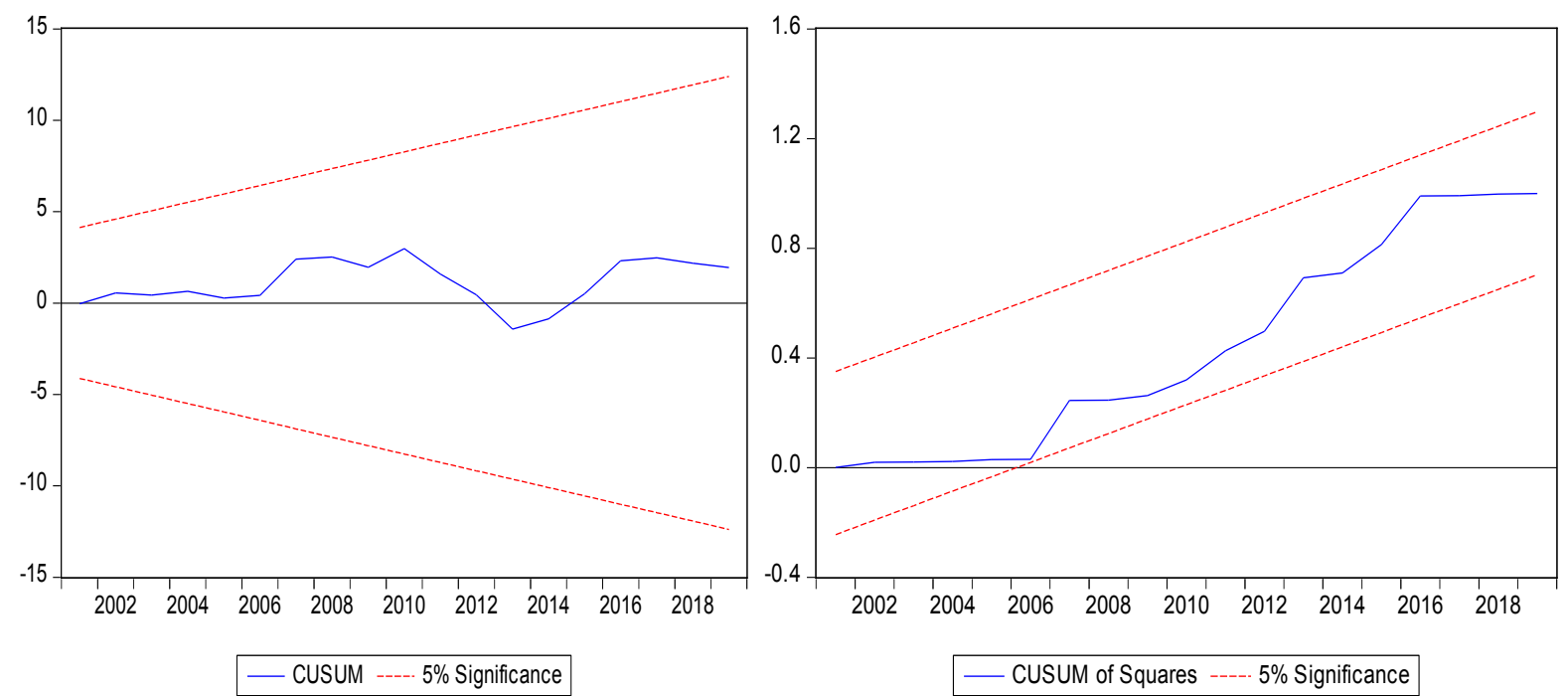

Model 1 


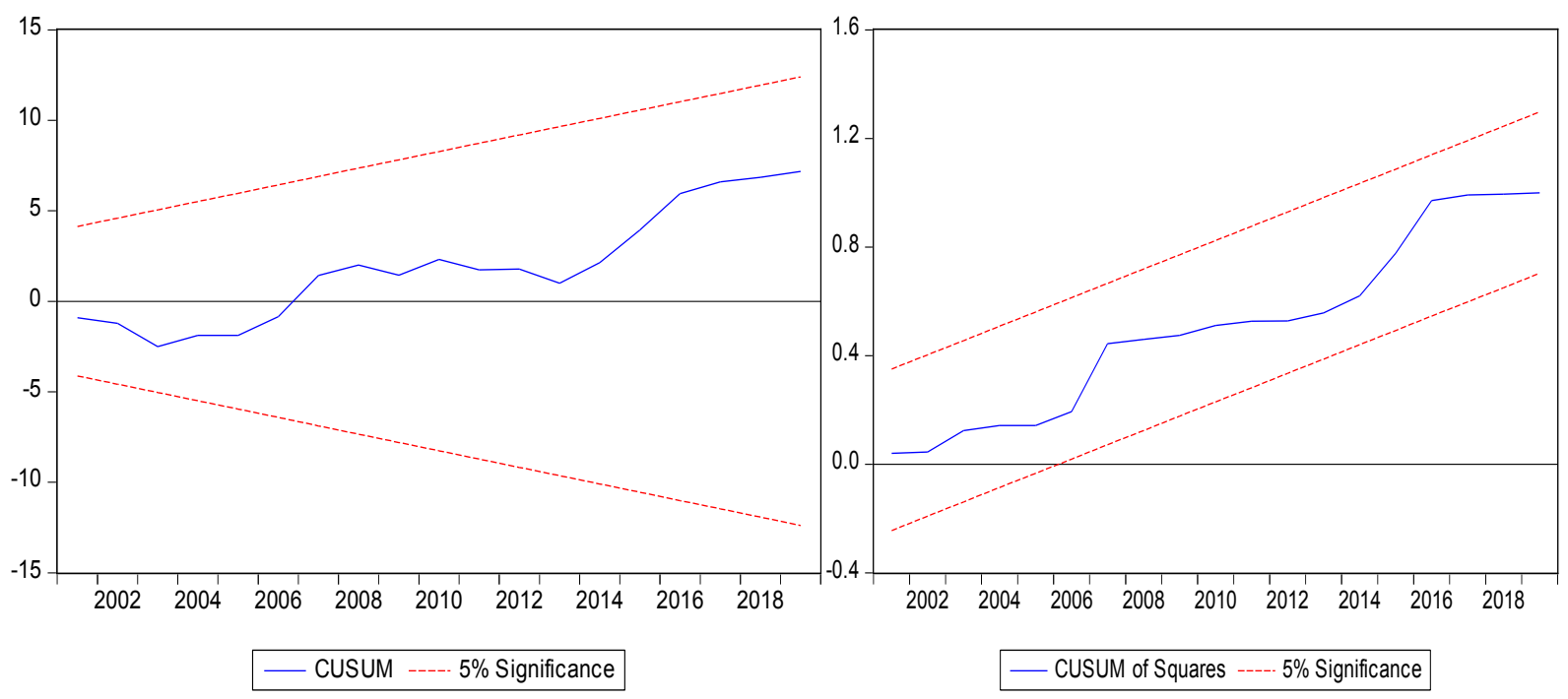

Model 2

Figure 2. Plot of CUSUM and CUSUMSQ

\section{Conclusions}

The aim of the study was to examine the nexus between financial development and economic growth in Bangladesh. This study employed the Autoregressive Distributed Lag (ARDL) model, taking annual data from 1987 to 2019. Financial development is the independent variable proxied by two key indicators: private sector loans and broad money supply. Besides, to get a better picture of the model, two control variables (viz. gross domestic savings and trade openness) are also included in the models. Finally, economic growth, the dependent variable, is proxied by the real GDP growth rate.

The study concludes that financial development plays a significant role in the economic development of Bangladesh in the long-run. In the event of gross domestic savings, this study has provided evidence of mixed results. It has no equal material effect on the sampled period of growth. For example, when private-sector loans is employed as a proxy for financial development, gross domestic savings do not have a credible impact on economic growth. At the same time, it is seen that financial development, proxied by the broad money supply, explains positively economic growth in the long-run. This study also finds a notable adverse effect of trade openness on the economic growth of the country. In the short-run, broad money supply at lag 2, as proxied for financial development, and gross domestic savings are proven to have a credible negative and positive impact on economic growth, respectively. In addition, the study also shows the favorable effect of trade openness on economic growth.

As policy implications, Bangladesh's economic growth plans should boost private sector credit and broad money supply. The cumulative rate of economic growth in
Bangladesh calls for more extensive availability of private sector loans and the supply of broad money. Therefore, the government of Bangladesh should ensure a sound environment for the banking sector so that it can securely disburse credit facilities to its prospective customers. The government should also focus on trade openness, as, unlike its long-run effect, trade openness reveals a noteworthy positive relationship with economic growth in the short-term. The government may implement such a policy that would reduce foreign trade deficits, excess trade fees, underdeveloped overland connections, ensure the use of the latest technology, protect native and infant industries, and intensify the country's exports. Bangladesh can now move away from its dependence on imports. Along with promoting private-sector investments, measures should be taken to prevent money laundering. It should also investigate the correct channeling of money supply into the overall economy. Governments should support and find a balanced macroeconomic atmosphere with good monetary and fiscal policies. Furthermore, the different government bodies in charge of monetary policy, law, and financial sector supervision must coordinate and collaborate.

The researchers highly recommend that widespread studies need to explore the proper linkage between finance and growth. This study is limited to the case of Bangladesh. Thus, the findings may not be applicable to other countries. To promote knowledge, future research should consider the potential effects of structural breaks more carefully.

\section{Acknowledgment}

The authors would like to thank K. M. Anwarul Islam 
and John M. Riveros for their continued support and encouragement and thank all the anonymous reviewers for their valuable comments.

\section{REFERENCES}

[1] World Bank, "World Bank Development Indicators," The World Bank, Washington, DC., 2020. https://data.worldban k.org/country/bangladesh.

[2] Asian Development Bank, "Asian Development Outlook (ADO) 2021: Financing a Green and Inclusive Recovery," 2021. [Online]. Available: https://dx.doi.org/10.22617/FLS 210163-3.

[3] M. S. Kayser and U. Golder, "Influence of Behavioral Factors, Market Factors and Stock Fundamentals on Individual's Investment Decision: A Study on Dhaka Stock Exchange," Jagannath Univ. J. Bus. Stud., vol. 7, no. 1\&2, pp. 79-96, 2019, [Online]. Available: https://www.research gate.net/publication/339427760_Influence_of_Behavioral Factors Market Factors and Stock Fundamentals on In dividual's_Investment_Decision_A_Study_on_Dhaka_Sto ck_Exchange.

[4] U. Golder, S. Akter, and M. I. Sheikh, "Response of Dividend Announcement on the Price of Mutual Fund: A Comprehensive Study on Mutual Fund Listed in Dhaka Stock Exchange (DSE)," Int. J. Sci. Res. Manag., vol. 7, no. 08 SE-Economics and Management, pp. 1276-1286, Aug. 2019, doi: 10.18535/ijsrm/v7i8.em02.

[5] K. Ben Jedidia, T. Boujelbène, and K. Helali, "Financial development and economic growth: New evidence from Tunisia," J. Policy Model., vol. 36, no. 5, pp. 883-898, 2014, doi: https://doi.org/10.1016/j.jpolmod.2014.08.002.

[6] M. K. Hassan, B. Sanchez, and J.-S. Yu, "Financial development and economic growth: New evidence from panel data," Q. Rev. Econ. Financ., vol. 51, no. 1, pp. 88 104, 2011, doi: https://doi.org/10.1016/j.qref.2010.09.001.

[7] S. Anwar and L. P. Nguyen, "Financial development and economic growth in Vietnam," J. Econ. Financ., vol. 35, no. 3, pp. 348-360, 2011, doi: 10.1007/s12197-009-9106-2.

[8] P. Arestis, G. Chortareas, and G. Magkonis, "The financial development and growth nexus: a meta-analysis," J. Econ. Surv., vol. 29, no. 3, pp. 549-565, Jul. 2015, doi: https://doi.org/10.1111/joes.12086.

[9] J. P. Bist and N. B. Bista, "Finance-Growth Nexus in Nepal: An Application of the ARDL Approach in the Presence of Structural Breaks," Vikalpa, vol. 43, no. 4, pp. 236-249, Dec. 2018, doi: 10.1177/0256090918813211.

[10] S. Amin and R. M. Hossain, "Finance-Growth Nexus in Bangladesh? An Empirical Analysis," Asian Econ. Financ. Rev., vol. 7, no. 2, pp. 152-163, 2017, [Online]. Available: https://econpapers.repec.org/RePEc:asi:aeafrj:2017:p:152163.

[11] M. Shahbaz, I. U. Rehman, and A. T. Muzaffar, "Revisiting Financial Development and Economic Growth Nexus: The Role of Capitalization in Bangladesh," South African J.
Econ., vol. 83, no. 3, pp. 452-471, Sep. 2015, doi: https://doi.org/10.1111/saje.12063.

[12] M. N. K. Biplob and P. Halder, "Financial Sector Development and Economic Growth: Empirical Evidence from Bangladesh," Asian Econ. Financ. Rev., vol. 8, pp. 799-814, 2018.

[13] S. Ioannou and D. Wójcik, "Finance and growth nexus: An international analysis across cities," Urban Stud., vol. 58, no. 1, pp. 223-242, Jan. 2020, doi: 10.1177/004209801988 9244.

[14] S. Cecchetti and E. Kharroubi, "Reassessing the impact of finance on growth," Bank for International Settlements, Jul. 2012. [Online]. Available: https://econpapers.repec.org/Re PEc:bis:biswps:381.

[15] R. Beck, G. Georgiadis, and R. Straub, "The finance and growth nexus revisited," Econ. Lett., vol. 124, no. 3, pp. 382-385, 2014, [Online]. Available: https://econpapers.rep ec.org/RePEc:eee:ecolet:v:124:y:2014:i:3:p:382-385.

[16] H. P. (Hyman P. Minsky, Stabilizing an unstable economy Hyman P. Minsky. New Haven: Yale University Press, 1986.

[17] G. Adu, G. Marbuah, and J. T. Mensah, "Financial development and economic growth in Ghana: Does the measure of financial development matter?," Rev. Dev. Financ., vol. 3, no. 4, pp. 192-203, 2013, doi: https://doi.org/10.1016/j.rdf.2013.11.001.

[18] R. Levine, "Chapter 12 Finance and Growth: Theory and Evidence," vol. 1, P. Aghion and S. N. B. T.-H. of E. G. Durlauf, Eds. Elsevier, 2005, pp. 865-934.

[19] J. A. Schumpeter and R. Opie, The theory of economic development; an inquiry into profits, capital, credit, interest, and the business cycle,. Cambridge, Mass.: Harvard University Press, 1934.

[20] R. W. Goldsmith, Financial structure and development, New Haven: Yale University Press, 1969.

[21] R. Hasan and S. Barua, "Financial Development and Economic Growth: Evidence from a Panel Study on South Asian Countries," Asian Econ. Financ. Rev., vol. 5, no. 10, pp. 1159-1173, 2015, doi: 10.18488/journal.aefr/2015.5.10 $/ 102.10 .1159 .1173$.

[22] Y. Wolde-Rufael, "Re-examining the financial development and economic growth nexus in Kenya," Econ. Model., vol. 26, no. 6, pp. 1140-1146, 2009, doi: https://doi.org/10.1016/j.econmod.2009.05.002.

[23] M. J. Abeka, E. Andoh, J. G. Gatsi, and S. Kawor, "Financial development and economic growth nexus in SSA economies: The moderating role of telecommunication development," Cogent Econ. Financ., vol. 9, no. 1, p. 1862395, Jan. 2021, doi: 10.1080/23322039.2020.1862395.

[24] R. Pradhan, "The Nexus between Financial Development and Economic Growth in India: Evidence from Multivariate VAR Model," 2009.

[25] D. Durusu-Ciftci, M. S. Ispir, and H. Yetkiner, "Financial development and economic growth: Some theory and more evidence," J. Policy Model., vol. 39, no. 2, pp. 290-306, 2017, doi: https://doi.org/10.1016/j.jpolmod.2016.08.001. 
[26] I. V. Edet, "Financial Deepening and Sustained Economic Growth in Nigeria," Universal Journal of Accounting and Finance, vol. 9, no. 4, pp. 565-573, 2021, doi: 10.13189/ujaf.2021.090404.

[27] B. E. Udoh, A. E. Jack, A. I. Prince, K.-I. L. Ekeowa, V. Ndubuaku, and U. E. Samuel, "Financial Deepening and Economic Growth in Nigeria: ARDL and NARDL Techniques," Universal Journal of Accounting and Finance, vol. 9, no. 4, pp. 667-677, 2021, doi: 10.13189/ujaf.2021.090413.

[28] J. B. Ang, "What are the mechanisms linking financial development and economic growth in Malaysia?," Econ. Model., vol. 25, no. 1, pp. 38-53, 2008, doi: https://doi.org/10.1016/j.econmod.2007.04.006.

[29] A. Rahman, M. A. Khan, and L. Charfeddine, "Financial development-economic growth nexus in Pakistan: new evidence from the Markov switching model," Cogent Econ. Financ., vol. 8, no. 1, p. 1716446, Jan. 2020, doi: $10.1080 / 23322039.2020 .1716446$

[30] A. Jahfer and T. Inoue, "Financial development, foreign direct investment and economic growth in Sri Lanka," Int. $J$ Econ. Policy Emerg. Econ., vol. 7, no. 1, pp. 77-93, Jan. 2014, doi: 10.1504/IJEPEE.2014.059889.

[31] R. P. Pradhan, M. B. Arvin, S. Bahmani, J. H. Hall, and N. R. Norman, "Finance and growth: Evidence from the ARF countries," Q. Rev. Econ. Financ., vol. 66, pp. 136-148, 2017, doi: https://doi.org/10.1016/j.qref.2017.01.011.

[32] M. Qamruzzaman and W. Jianguo, "Financial innovation and economic growth in Bangladesh," Financ. Innov., vol. 3, no. 1, p. 19, 2017, doi: 10.1186/s40854-017-0070-0.

[33] E. Iheanacho, "The Impact of Financial Development on Economic Growth in Nigeria: An ARDL Analysis," Economies, vol. 4, no. 4. 2016, doi: 10.3390/economies404 0026.

[34] M. N. Siddikee and M. M. Rahman, "Foreign Direct Investment, Financial Development, and Economic Growth Nexus in Bangladesh," Am. Econ., p. 0569434520938673,
Jul. 2020, doi: 10.1177/0569434520938673.

[35] D. Christopoulos and M. Tsionas, "Financial development and economic growth: evidence from panel unit root and cointegration tests," J. Dev. Econ., vol. 73, no. 1, pp. 55-74, 2004, [Online]. Available: https://econpapers.repec.org/Re PEc:eee:deveco:v:73:y:2004:i:1:p:55-74.

[36] S. Johansen, "Estimation and Hypothesis Testing of Cointegration Vectors in Gaussian Vector Autoregressive Models," Econometrica, vol. 59, no. 6, pp. 1551-1580, Apr. 1991, doi: $10.2307 / 2938278$.

[37] R. F. Engle and C. W. J. Granger, "Co-Integration and Error Correction: Representation, Estimation, and Testing," Econometrica, vol. 55, no. 2, pp. 251-276, May 1987, doi: $10.2307 / 1913236$.

[38] M. H. Pesaran, Y. Shin, and R. J. Smith, "Bounds testing approaches to the analysis of level relationships," J. Appl. Econom., vol. 16, no. 3, pp. 289-326, May 2001, doi: 10.1002/jae.616.

[39] M. Bahmani-Oskooee and M. T. Bohl, "German monetary unification and the stability of the German M3 money demand function," Econ. Lett., vol. 66, no. 2, pp. 203-208, 2000, [Online]. Available: https://econpapers.repec.org/Re PEc:eee:ecolet:v:66:y:2000:i:2:p:203-208.

[40] U. Golder, M. N. Islam, and M. S. Kayser, "Impact of Foreign Exchange Reserve, Exchange Rate and Crude Oil Price on Dhaka Stock Exchange Index: An Empirical Evidence from Vector Error Correction Model," Indian J. Financ. Bank., vol. 4, no. 1 SE-Research Articles, Jun. 2020, doi: 10.46281/ijfb.v4i1.633.

[41] M. H. Rahman, "Financial Development: Economic Growth Nexus in Bangladesh," SSRN Electron. J., Jan. 2007, doi: 10.2139/ssrn.1310460.

[42] U. Golder, M. I. Sheikh, and F. Sultana, "The Relationship Between Foreign Aid and Economic Growth: Empirical Evidence from Bangladesh," J. Asian Financ. Econ. Bus., vol. 8, no. 4, pp. 625-633, Apr. 2021, doi: 10.13106/JAFEB.2021.VOL8.NO4.0625. 